\title{
ULTRASTRUCTURAL STUDY OF THE LATERAL VENTRICLE CHOROID PLEXUS IN EXPERIMENTAL HYDROCEPHALUS IN WISTAR RATS
}

\author{
Daniela Pretti da Cunha Tirapelli', Luiza da Silva Lopes², João José Lachat², \\ Benedicto Oscar Colli², Luís Fernando Tirapelli
}

\begin{abstract}
Hydrocephalus is one of the most frequent and complex neurological diseases characterized by the abnormal buildup of cerebrospinal fluid (CSF) in the ventricles of the brain, due to an altered CSF dynamics. To detect possible ultrastructural alterations of the lateral ventricles choroid plexus (responsible for the CSF production), rats seven days after birth were submitted to an intracisternal injection of $20 \%$ kaolim (hydrated aluminum silicate) for the hydrocephalus induction. Twenty-eight or 35 days after injection, injected animals and respective controls were processed for observation under a transmission electron microscopy. Alterations found: presence of concentric cell membrane fragments, larger number of primary and secondary lysossomes, vacuoles, and cytoplasmic vesicles, and an enlargement of the intercellular space and between the basolateral interdigitation of the choroid epithelium. The alterations observed are probably associated to an increase of the ventricular pressure, inducing morpho-functional effects on the choroid plexus integrity.
\end{abstract}

KEY WORDS: hydrocephalus, choroid plexus, ultrastructural study, rat.

Estudo ultraestrutural dos plexos corióides dos ventrículos laterais de ratos Wistar submetidos a hidrocefalia experimental

RESUMO - A hidrocefalia é uma das mais freqüentes e complexas doenças neurológicas caracterizada pelo acúmulo de líquido cefalorraquidiano (LCR) no interior dos ventrículos cerebrais e conseqüente alteração na dinâmica liquórica. Para detectar as possíveis alterações ultra-estruturais nos plexos corióides dos ventrículos laterais (responsáveis pela produção do LCR), ratos sete dias após o nascimento, foram submetidos à indução de hidrocefalia pela injeção intracisternal de caulim a 20\%. Após 28 e 35 dias da injeção, estes animais e seus respectivos controles foram processados para observação em um microscópio eletrônico de transmissão. Alterações observadas: presença de membranas concêntricas, maior número de lisossomos primários e secundários, vacúolos e vesículas citoplasmáticas, aumento do espaço intercelular e entre as interdigitações basolaterais das células do epitélio corióideo. As alterações observadas possivelmente estão associadas ao aumento da pressão nos ventrículos, induzindo efeitos morfo-funcionais na integridade dos plexos corióides.

PALAVRAS-CHAVE: hidrocefalia, plexos corióides, estudo ultra-estrutural, rato.

Hydrocephalus is one of the most frequent and complex neurological diseases characterized by the abnormal buildup of cerebrospinal fluid (CSF) in the ventricles of the brain, due to an altered CSF dynamics. The hydrocephalus is a result of multiple pathophysiological mechanisms, with many different causes including a birth defect, hemorrhage into the brain, infection, meningitis, tumor, or head injury. In this way, the treatment possibilities as also the ideal time to introduce it has been widely studied'. Kaolin has been widely used to induce hydroceph- alus in several developmental stages of experimental animals including neonates and adults. This model of experimental induction was chosen due to it being efficient, inexpensive, and it does not need surgical proceedings or cause anatomic modifications and does not even lead to other alterations unless those results that are totally of hydrocephalus ${ }^{2-7}$.

As responsible for the CSF production, the choroid plexus play an important role on the central nervous system (CNS) homeostasis. Because of its situation in the lateral ventricles of the brain, the choroid plexus

\footnotetext{
'Pos-graduate Student, Department of Surgery and Anatomy, Medicine School of Ribeirão Preto, University of São Paulo, Ribeirão Preto SP, Brazil (FMRP/USP); ${ }^{2}$ Professor, Department of Surgery and Anatomy, FMRP/USP.

Received 11 April 2007, received in final form 2 July 2007. Accepted 16 August 2007.

Dr. Luis Fernando Tirapelli - Departamento de Cirurgia e Anatomia / Campus Universitário / FMRPIUSP - 14048-9oo Ribeirão Preto SP - Brasil. E-mail: tirapeli@fmrp.usp.br
} 
are involved by hydrocephalus in its early stages ${ }^{8,9}$. Del Bigio et al. ${ }^{10}$ and Kiefer et al. ${ }^{11}$ observed reduced density of ependymal microvilli, vacuolar formation and cellular inclusions on choroid cells, and intercellular space enlargement, after experimentally induced hydrocephalus. Go et al. ${ }^{12}$ and Madhavi and Jacob ${ }^{13}$ observed the presence of Kolmer fagocytic cells on the ependymal cells surface and on the choroid cells in hydrocephalic animals. Also, by means of morphometry, these authors have found a significant decrease of surface volume and area of the choroid epithelium in hydrocephalic animals, compared to controls. Alterations on the choroid plexus in hydrocephalic animals are not well established in the literature.

In order to contribute for a better understanding of the hydrocephalus pathologic alterations of brain structures, the aims of the present study were to detect, by means of transmission electron microscopy (TEM), the alterations on lateral ventricles choroid plexus of Wistar rats, with experimentally induced hydrocephalus.

\section{METHOD}

Twenty-four litters of 7-day old Wistar rats were used, without sexual distinction. Each litter was constituted of the mother rat and 8 newborn rats. Two groups of animals were submitted to the hydrocephalus induction with intracyster- nal injection of $20 \%$ kaolin (after 28 or 35 days of injection) and the third group was used as control ${ }^{14,15}$. Each pup rat was held by an auxiliary, who held the head with one hand and the body with the other, bending the animal's neck, leaving the posterior cervical area free. By palpation the space between the posterior extremity of the foramen magnum, on the occipital bone, and the posterior arch of the first cervical vertebra was identified. With a Mise 0.3 odontologic needle, with a short bezel, the suboccipital percutaneous injection was done, and $0.4 \mathrm{~mL}$ of a kaolin suspension (Merck) diluted in distilled water of $20 \%$ was slowly injected. Following this the rats were put back into their cages with their mothers.

The animals of each group injected with kaolin, and their respective controls of the same age, were anesthetized with vapors of sulphuric ether and submitted to a transcardiac perfusion with PBS solution (about $1 \mathrm{~mL} / \mathrm{g}$ of the animal's weight), after the perfusion, with the same volume, with a $2 \%$ paraformaldehyde and $1 \%$ glutaraldehyde in a $0.1 \mathrm{M}, \mathrm{pH}$ 7.4 phosphate buffer. The animals were decapitated, their brains removed in block by a craniectomy of the vertex and immersed in the same fixative solution of formaldehyde and glutaraldehyde for more than 24 hours at $4^{\circ} \mathrm{C}$.

After washing with a $0.1 \mathrm{M}$ phosphate buffer, the brains were sectioned at the coronal plane, and the choroid plexuses identified and removed. The samples from the choroid plexuses were fixed in a $1 \%$ osmium tetroxide in a $0.2 \mathrm{M}$ phosphate buffer for 2 hours, at $4^{\circ} \mathrm{C}$, washed with a $0.1 \mathrm{M}$ phosphate buffer and then dehydrated in an increasing series of acetone and embedded in araldite. After the polymerization of the resin, the blocks were cut in sections of $0.5 \mu \mathrm{m}$ (semi-
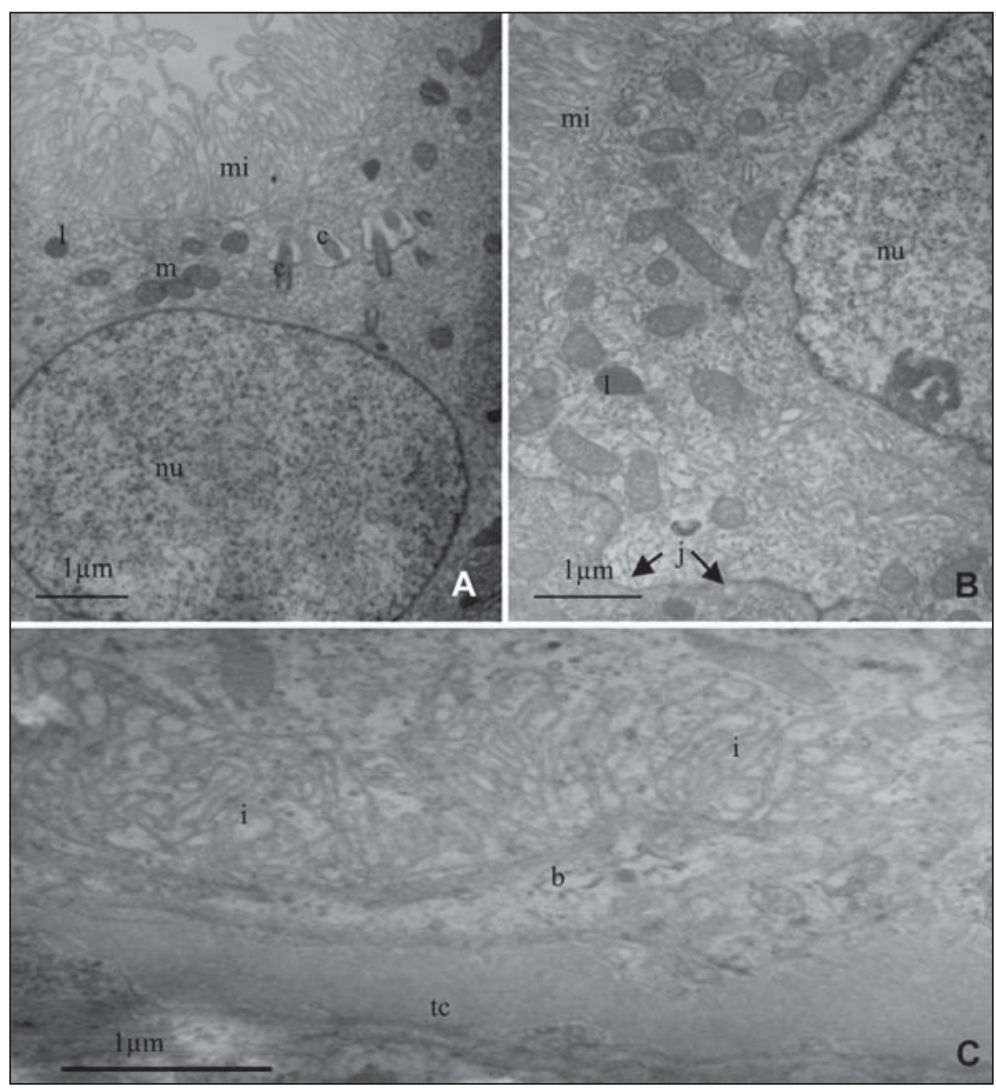

Fig $1 A, 1 B$ and $1 C$. Electron micrographs of the lateral ventricle choroid plexus of control rats. Cilia (c); interdigitation (i); intercelular junction (j); basal lamina (b), lysosome (I); mocrovilii (mi), mitochondria (m); nucleus (nu), connective tissue (tc). 10000x; 13000x, 13000x. 


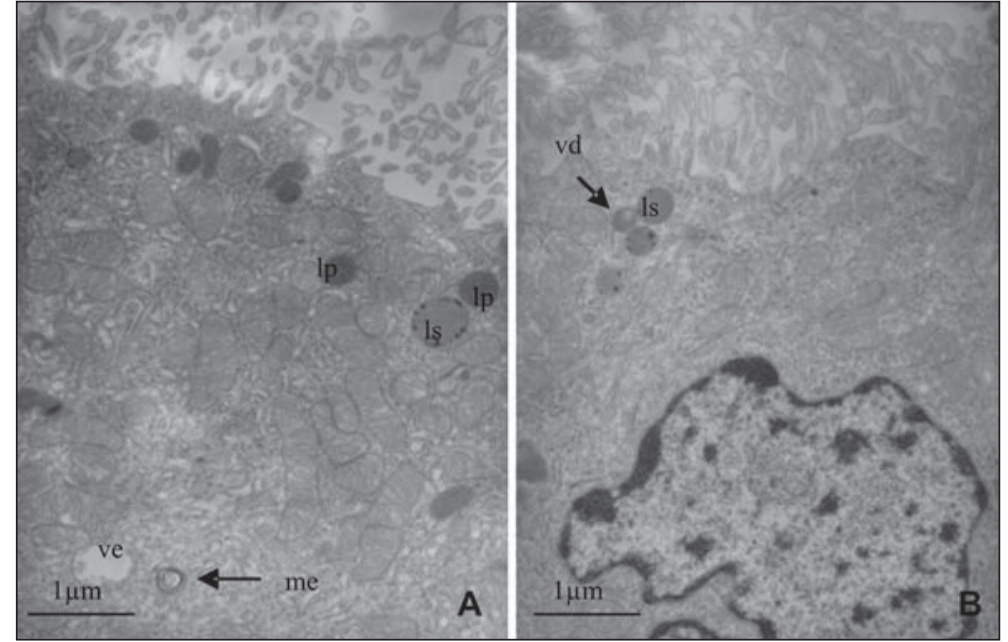

Fig $2 A$ and $2 B$. Electron micrographs of the lateral ventricle choroid plexus of rats $28(2 A)$ and 35 $(2 B)$ days after hydrocephaly induction. Concentric membranes, similar to myelin (me); primary (Ip) and secondary (Is) lysosomes; digestive vacuoles (vd), electron-lucid containing vesicles (ve). 13000x; 11000x.

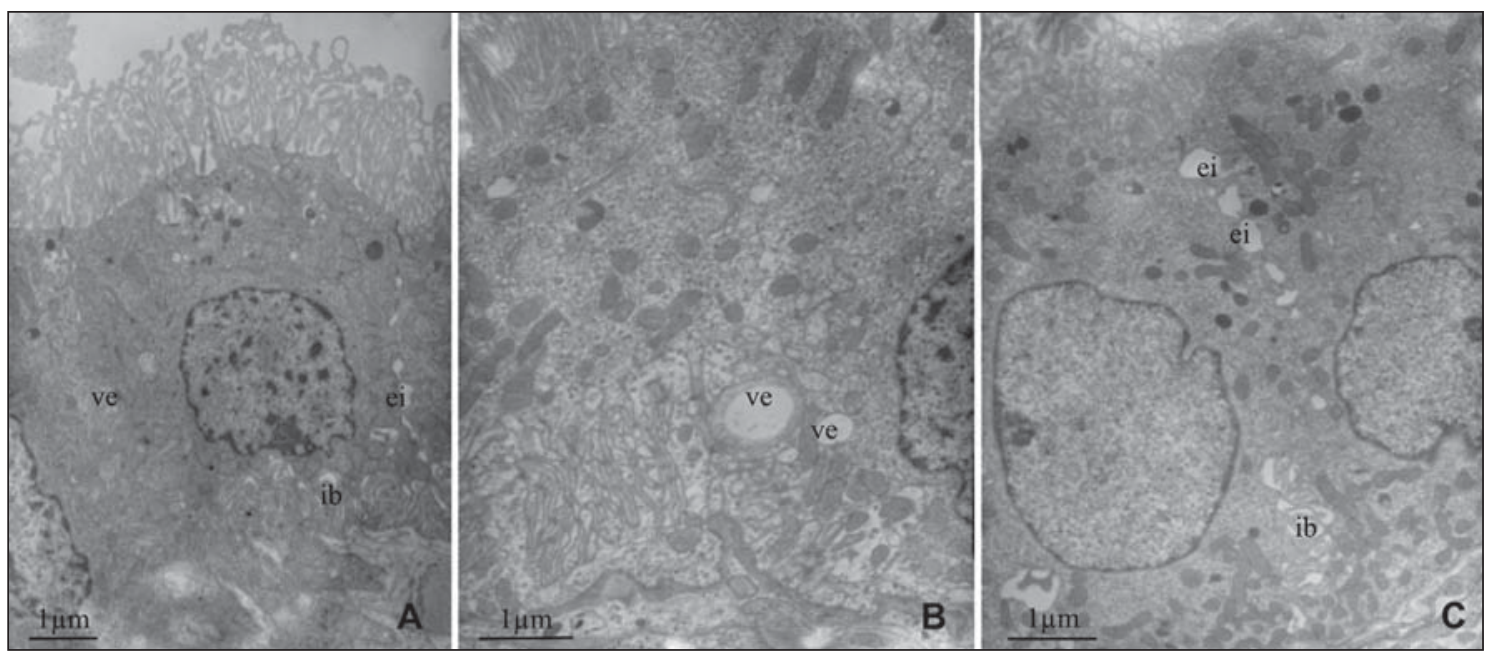

Fig $3 A, 3 B$ and 3 C. Electron micrographs of the lateral ventricle choroid plexus of rats 35 days after hydrocephaly induction. Enlargement of the intercellular space (ei) and the basolateral interdigitation (ib); electron-lucid containing vesicles (ve). 8000x; 13000x; 10000x.

fines) and after $500 \AA$ of thickness. The sections were stained with uranil and lead citrate and examined in a EM 208 Philips TEM. All experimental procedures were performed accordingly with the Ethical Principles in Animal Research adopted by Brazilian College of Animal Experimentation (COBEA) and was approved by the College of Medicine of Ribeirão Preto of the University of São Paulo - Ethical Commission of Ethics in Animal Research (CETEA), protocol n 133/2006.

\section{RESULTS}

The choroid epithelium is ultrastructuraly described as simple columnar, presenting many microvilii on the ventricle surface and the occasional presence of cilia ${ }^{16}$ (Figs $1 \mathrm{~A}$ and $1 \mathrm{~B}$ ). The cells cytoplasm presents a large central nucleus, mitochondria, rough endoplasmic reticulum, Golgi complex and occasional lysossomes. A joint complex is found on the apical junction of the cells (Fig $1 \mathrm{~B}$ ) as a basolateral membrane full of interdigitation (Fig 1C). Choroid epithelial cells lay on a dense basal lamina. Beneath this lamina, a small amount of loose connective tissue with collagen fibers separate the basal lamina (Fig $1 C$ ) and the main capillary vessels, formed by a thin endothelium ${ }^{17-21}$.

On animals of the control groups, no alterations were seen. On both experimental groups ( 28 and 35 days after kaolin injection), the following alterations were found: presence of concentric cell membrane fragments, similar to the myelin sheath on the cytoplasm (Fig 2A), larger number of primary and secondary lysossomes (Figs $2 \mathrm{~A}$ and $2 \mathrm{~B}$ ), vacuoles (Fig $2 \mathrm{~B}$ ), and cytoplasmic vesicles of different sizes, containing an electron-lucid material (Figs $2 \mathrm{~A}, 3 \mathrm{~A}$ and $3 \mathrm{~B}$ ). On animals 35 days after kaolin injection, an enlargement of the intercellular space and between the basolateral interdigitation of the choroid epithelium was also 
seen (Figs $3 \mathrm{~A}$ and ${ }_{3} \mathrm{C}$ ).

\section{DISCUSSION}

Among the main functions of the choroid plexus is the CSF production. Nevertheless, it is well known the role of the choroid plexus in the nutrition and protection of the CNS since the CSF is a chemically stable fluid ${ }^{19,21}$. The choroid plexus is able to transfer nutrients to the CSF, actively regulating the molecules concentration of this fluid and determining the selective characteristics of the blood-CSF barrier ${ }^{21}$. The choroid plexus also present a role on the CSF clearance of drugs and substances formed on the brain tissue due to the metabolic reactions, thus presenting several active-transport systems ${ }^{9,21}$. The first structure to suffer on the hydrocephalus process in high CSF pressure is the ependymal epithelium, with compression, distension and isolated disruption ${ }^{10,11}$.

Go e tal. ${ }^{12}$ and Go and Molenaar ${ }^{22}$ observed the infestation of Kolmer fagocytic cells on the ependymal cells and choroid cells surface, as well as a degeneration of ependymal cilia. The fragments observed on the choroid plexus surface of hydrocephalic animals are consequence of an impaired ciliar movement due to the ciliar degeneration described previously ${ }^{12,22}$. In this way, an altered CSF dynamics and the CSF accumulation on an enlarged ventricular system impairs the correct elimination of the metabolic products ${ }^{23}$.

Del Bigio et al. ${ }^{10}$, Madhavi and Jacob ${ }^{13}$ and Kiefer et al." have observed alterations on the choroid epithelium such as microvilii distortion, atypical cilia, flatten cells with and vacuoles, intracellular inclusions and enlargement of intercellular space. Some of these alterations were also seen on the present study. In this way, the vesicles containing electron-lucid material observed on the choroid cells might be the result of a fluid penetration into the cytoplasm. The presence of a large amount of lysossomes, secondary lysosomes and digestive vesicles might suggest that there is a secretion and absorption impairment of CSF products or the cytoplasmic organelles death. In a morphometric study, Madhavi and Jacob ${ }^{24,25}$ have shown a significant decrease on the volume and area of the choroid epithelium in hydrocephalic animals. Also, these authors shoed a reduction of the mitochondrial internal membrane area, including the crests, which was attributed to a decreased activity of the choroid cells, followed by a reduction on the CSF secretion on those animals.

In conclusion, the choroid plexus is the main structure responsible for production and maintenance of the CSF homeostasis, an essential factor for the development and normal functioning of the CNS. In this way, the alterations observed in this structure are associated to an increase of the ventricular pressure, inducing morpho-functional effects on the choroid plexus integrity, contributing to several morpho-functional alterations of the $\mathrm{CNS}^{26}$.

\section{REFERENCES}

1. Sato O, Oi S, Yamada S. Hydrocephalus: experimental considerations and clinical analyses. In Choux M, Di Rocco C, Hockley AD, Walker ML (Eds). Pediatric neurosurgery. London: Churchill Livingstone, 1999:237-252.

2. Del Bigio MR, Massicotte EM. Protective effect of nimodipine on behavior and white matter of rats with hydrocephalus. J Neurosurg 2001;94:788-794.

3. Khan OH, Enno TL, Del Bigio MR. Brain damage in neonatal rats following kaolin induction of hydrocephalus. Exp Neurol 2006;200:311-320.

4. Kondziella D, Ludemann W, Brinker T, Sletvold O, Sonnewald U. Alterations in brain metabolism, CNS morphology and CSF dynamics in adult rats with kaolin-induced hydrocephalus. Brain Res 2002:8:35-41.

5. Kuchiwaki H, Nagasaka M, Inao S, Sugita K. Progression of kaolin-induced hydrocephalus and changes in performance of operant tasks by rats. J Neurol Sci 1994;121:32-38.

6. Matsumoto S, Hirayama A, Yamasaki S, Shirataki K, Fujiwara K. Comparative study of various models of experimental hydrocephalus. Childs Brain 1975;1:236-242.

7. Tashiro Y, Chakrabortty S, Drake JM, Hattori T. Progressive loss of glutamic acid decarboxylase, parvalbumin, and calbindin D28K immunoreactive neurons in the cerebral cortex and hippocampus of adult rat with experimental hydrocephalus. J Neurosurg 1997;86:263-271.

8. Del Bigio MR, MCallister JP. Hydrocephalus: pathology. In Choux M, Di Rocco C, Hockley AD, Walker ML (Eds). Pediatric neurosurgery. London: Churchill Livingstone, 1999:217-236.

9. Machado A. Neuroanatomia funcional. 2.Ed. Rio de Janeiro: Editora Atheneu, 2000 .

10. Del Bigio MR, Bruni JE, Fewer HD. Human neonatal hydrocephalus: an electron microscopic study of the periventricular tissue. J Neurosurg 1985;63:56-63

11. Kiefer M, Eymann R, Von Tiling S, Muller A, Steudel I, Booz KH. The ependyma in chronic hydrocephalus. Child's Nerv Syst 1998;14:263270

12. Go KG, Stokroos I, Blaauw EH, Zuiderveen F, Molenaar I. Changes of ventricular ependyma and choroids plexus in experimental hydrocephalus, as observed by scanning electron microscopy. Acta Neuropathol 1976;34:55-64.

13. Madhavi C, Jacob M. Atypical cilia in the choroid plexus of guineapig. Indian J Med Res 1989;90:484-489.

14. Lopes LS, Machado HR, Lachat JJ. Study of corpus callosum in experimental hydrocephalic wistar rats. Acta Cirurg Bras 2003;18:10-14.

15. Lopes LS, Machado HR, Lachat JJ. Hidrocefalia experimental. In Castro e Silva O Jr., Zucoloto S, Beer A Jr. (Eds). Modelos experimentais de pesquisa em cirurgia. São Paulo: Robe Editorial, 1998:753-772.

16. Junqueira LCU, Carneiro J. Histologia básica. 9.Ed. Rio de Janeiro: Editora Guanabara Koogan SA, 1999.

17. Meek WJ. A study of the choroid plexus. J Comp Neurol Psychol 1907:17:286-306.

18. Zimman L. Investigaciones sobre la estractura de los plexos coroideos em estado normal y patológico. Arch Histol 1943;1:278-328.

19. Dohrmann GJ. The choroid plexus: a historical review. Brain Res 1970; 18:197-218.

20. Peters A. The surface fine structure of the choroid plexus and ependymal lyning of the rat lateral entricle. J Neurocytol 1974;3:99-108.

21. Spector R, Johanson CE. Plexos coroideos de los mamíferos. Invest Ciencia 1989;226:44-51.

22. Go KG, Molenaar I. Some applications of scanning electron microscopy for the study of biopsies in central nervous system pathology. Scan Electron Microsc 1983;143-150.

23. Castro-Gago M, Rodriguez IN, Rodriguez-Nunez A, Guitian JP, Rocamonde SJ, Roodriguez-Segade S. Therapeutic criteria in hydrocephalic children. Child's Nerv Syst 1989;5:361-363.

24. Madhavi C, Jacob M. Morphometry of choroid plexus in hydrocephalic guineapigs. Indian J Med Res 1990;92:89-94.

25. Madhavi C, Jacob M. Morphometry of mitochondria in the choroidal ependyma of hydrocephalic guineapigs. Indian J Med Res 1992;96:72 77.

26. Craciun C, Checiu I, Craciun V. Ultrastructural changes in the mouse fetal choroid plexuses following chronic maternal alcoholization. Rev Roum Morphol Embryol Physiol 1989;35:221-226. 